\title{
Designing a Customer Retention Framework for Telecommunication Sector
}

\author{
Ahmad Sohail Khan ${ }^{* 1}$, Saima Majeed², Rizwan Shabbir ${ }^{1}$ \\ ${ }^{1}$ Government College University, Faisalabad, Pakistan \\ ${ }^{2}$ National University of Modern Languages, Islamabad, Pakistan \\ *ahmadsohailkhan@gcuf.edu.pk, saimamahr33@yahoo.com,rizwanshabbir@gcuf.edu.pk
}

\begin{abstract}
Telecommunication sector has grown over last decade while transforming behavioral intentions. New entrants are exploring these behavioral intentions to attract more customers. The aim of this study is to investigate the mediating effect of customer satisfaction in telecom industry on service quality, brand image and customer retention relationship. Furthermore, it identifies the key determinants of customer retention related to telecom service providers. A fully structured questionnaire survey was conducted to collect data from 310 mobile users. Non-probability sampling technique was adopted for data collection. Regression analysis and Sobel test technique were practiced to analyze the data. The result showed that customer satisfaction mediates the relationship between service quality, brand image and customer retention. Moreover, this study found that service quality, brand image and customer satisfaction are the strongest predictors of customer retention in telecom industry of Pakistan. Therefore, to gain customer loyalty, organizations should focus current-users and target-users by providing sterling service quality.
\end{abstract}

Keywords: Service quality, Brand image, Customer satisfaction, Customer retention

\section{Introduction}

In the recent years, telecommunication industry of Pakistan has drawn scholarly attention because of its ever changing market dynamics. As the cellular phones have been taken place as one of the most preferred household utilities with ever increasing tele-density across the board. Inclusion of new entrants has made the industry even competitive, swift, sophisticatedly motorized and service quality oriented. It has been emerged as one of the most interesting sector to study, research, investigate and forecast the future of the industry (Ali et al., 2010). The extant warfare in the industry has two dimensions apparently, one is the unfair price competition and snatching the consumers amongst the competitors is the other one. This has been quite evident in Television Commercials (TVC's) on-air by Telenor, Mobilink and U-fone. Thus, the fact is known to the companies that ultimate success is hidden somewhere in creating new customers, satisfying and retaining the existing ones. When pleased customer purchases any services, it is likely to be retained with the company for a longer time (Kouser et al., 2012). In the context of relationship marketing, customer satisfaction is often viewed as one of the central determinants of customer retention. Prior studies concluded that customer satisfaction with company's offerings is often seen as crucial for victory and long-term competitiveness. Thus, Customer retention is key of success for all organizations such as the cost of attaining a new buyer is more than keeping a relationship with an existing customer.

According to Rust\& Zahorik (1993) Customer's retention leads companies towards better performance. Therefore, it is beneficial as well as less costly (Yoshida \& James, 2010). An organization bears the cost of attaining new customer at initial stage of commercial relationship then retaining old customers is least expensive as compared to grabbing new ones. These satisfied customers would help in creating and propagating goodwill of the organization (Ahmad et al., 2010). The work of Reichheld (1996) summarized that brand image attracts the customers towards product and they get more satisfied resultantly. On the other hand, if brand image is positive, the perceived service quality also increases customer's satisfaction level (Parasuraman et al., 1988). With respect to Telecom, markets are characterized on the basis of high technology and short product life cycle. In this scenario, Service quality plays a very important role in building up a strong and ever lasting relationship. Service quality can be achieved by the distribution of superior service to the customers according to their lay down expectations level (Cronin \& Taylor, 1992; Santos, 2003). The three essential features of service quality were quality, physical service environment quality and interaction quality. Prior studies explained these three broad dimensions of renowned construct of service quality system called SERVQUAL. SERVQUAL has five dimensions: tangibles, reliability, responsiveness, empathy and assurance (Parasuraman et al., 1988). The first measurement based on 
tangibles with physical environment; the reliability corresponds with service outcome and the remaining three deal with interaction quality aspects.

Moreover, latest developments in the literature showed that service quality is precursor of the theory of customer satisfaction (Lee et al., 2000) and the relationship between loyalty and service quality is intervened by satisfaction (Caruana, 2002). Thus, loyal customers have a strong commitment to a brand, because they believe that brand is more satisfactory than the alternatives (Holland \& Baker, 2001). The market place continually brings new challenges and organizations respond to these challenges by designing innovative customer retention strategies (Tsoukatos \& Rand 2006). Telecom industry has many opportunities for researcher as well as business itself (Ali et al., 2010). The number of customers got increased from 68,000 to 3.3 million from 1996 to 2003. Later it turns out to be up to 88 million at the start of 2008 then raised above to 95 million by the end of 2009. At the end of 2014 it turns out 139.90 million (PTA, 2014).Telecom service providers are using various integrated marketing communication tools for satisfying customers and competing with rivals. However, it has also been observed by many researchers that all telecom operators are engaged in a price-war to capture market share. Nowadays, intense competition is prevailing among cellular organization because they are unable to retain current-users due to fast technological changes which change behavioral intentions among target customers. Services of different market players are near unable to create and maintain visible differences amongst themselves. Brand image seems to fade out gradually in telecom industry of Pakistan. In this scenario, the companies encounter to design an ever-lasting customer retention strategy providing best service quality and advocating brand image.

\section{Literature Review}

Services sector is vital in developing economies because they are becoming imperative in everyday life as behavioral intentions among customer transform due to their demand. Customer satisfaction is the assessment of the experience of interacting with a service provider up to the present time, and is used by customers to predict future experience. Satisfaction is a broad feeling that is affected by the quality of service and the product, its price and other contextual and personal factors (Sum Chau \& Kao, 2009). In relationship marketing, loyalty is most important because it is a long-term commitment from the existing customers for the repurchase of services (Cavana et al., 2007). So, loyal customer often became a retain customer which is very beneficial for service organizations.

Perceived Service Quality: The work of Parasuraman et al. (1988) described service quality as consumer's experience about the product or services, they are using. Service quality is fastest growing area for researcher's and now necessitate additional information is required according to prospects of customers (Parasuraman et al., 1994). Therefore, services quality is the customer's overall impression of the relative advantages to the organization and it's provided services. The study of Oh (1999) summarized that service quality; customer satisfaction and customer value have momentous constructive relationship. Many researchers have computed service quality by adopting SERVQUAL scale which was designed by Parasuraman et al. (1988) and has six dimensions enclosed within effectiveness and assurances, access, price, services portfolio, reliability and tangibles (Bahia and Nantel, 2000). The work of Zeithaml (2000) described that these six dimensions impact various organizational performance such as first type of service quality directly influenced the profit, second explained offensive effects, third category demonstrate defensive effects, fourth is about the association between perceived Service quality and purchase intention, fifth dimension is about customers, profitability and segmentations and last-category clarified key service drivers of service quality.

Service quality and customers satisfaction have bi-directional association which means satisfaction has effect on service quality and service superiority influence customer pleasure and their retention in return and moves in two way direction (Lee et al., 2000). Moreover, service quality is significantly interrelated to purchase intention and customers satisfaction (Lee \& Lin, 2005). The study of Henkel et al. (2006) explored that satisfied customer has positive purchase intention in future and their product usage level also increased due to higher service quality. Thus, Service quality enhances profitability through developing relationship with customer satisfaction (Yang et al., 2004). In telecom sector, future purchase intentions rely upon superior service quality. However, customer perceptions are also changing with passage of time, need, 
circumstances that effect customer satisfaction (Casadesus, 2014). The work of Kim et al. (2004) summarized that service quality is as competitive weapon through which customers are more attracted because it creates better customer satisfaction and long term association. The Service quality model has a strongest influence towards predicting customer retention (Ngie \& George, 2014). According to Orel \& Kara (2014) loyal customer are five-times less costly as compared to a new customer because he/she is satisfied with the product/service quality. Service quality is basically a process of intangible activities which makes customer happy and leads towards retention. However, culture differences also affect the relationship between service quality and satisfaction which showed that high uncertainty avoidance customers were less satisfied as compared to low uncertainty avoidance customers. Within the limelight of telecom zone concept, the finding suggested a narrower range of acceptable outcomes for high-uncertainty avoidance cultures (Reimann et al., 2008). The work of Ahmed et al. (2010) explored that telecom industry primary need is to put all resources and energy to offer new services for the subscriber which meet their expectations and tries to satisfy customers by offering valuable services. If firms meet with actual need and expectation than customers will be converted into satisfied customers and can generate a long-term relationship (Lin\& Wu, 2011). When customers feel pleasure and happy from current service quality then he/she will make more transactions. Based on literature, we proposed that:

$\mathbf{H}_{1}$ : Better the perceived service quality, the customer's retention is more likely to be enhanced.

Brand Image: Brand is a design, name or figure, symbol, or the mark of the combination of all (Aaker, 1991). Moreover, Brand image is the assets of organization in this era of competition when firms struggle to gain competitive edge by providing differentiate services (Yeh, 2014). Brand image has a strong association with customer mind which result a strong relationship of brand image, customer satisfaction and future intention (Sondoh et al., 2007). Furthermore, a positive brand image could influence customer loyalty that persuades them to repurchase those product/services. From organizational perceptive, higher level of corporate image leads to generate high customer retention (Christopher, 1996). The study of Davies et al. (2003) concluded that brand image has a strong effect on perceived service quality and customer satisfaction. Moreover the satisfaction also leads to the customer loyalty (Chiang \& Jang, 2007). According to Ogba and Tan (2009), Telecommunication sector faces big competitive challenges i.e. customers expect more from brand name further they also concluded that perceived service quality have impact on Brand image. Moreover, Brand image is very effective to enhancing loyalty programs such as customer retention (Hanzaee \& Farsani, 2011). Thus, brand Image is an evaluation between customer expectation and firm's solution and brand image lead towards customer retention (Boohene \& Agyapong, 2011). To gain competitive advantage in market, essential aspects are service quality, corporate image, service value and customer satisfaction through which firms can predict different behavioral intentions and generate ever-lasting relationship with customers. Tsai (2014) concluded that brand advocacy have strong impact on customer satisfaction with influence on switching resistance and loyalty in developing a long-term relationship with customers. Mansouri and Pakia (2015) analyzed behavioral intentions in which they concluded that brand image and service quality has showed impact on customer satisfaction and commitment. Thus, Strong brand image makes customer satisfied and produce brand loyalty and through which organizations gain competitive edge and brand loyalty (Ene \& Ozkaya, 2014). Based on given literature, following hypothesis is proposed:

$\mathbf{H}_{2}$ : Likelihood of customer's retention is affected positively by the brand image.

Customer Satisfaction: According to Brown and Chin (2004) Customer's satisfaction relies on service quality that should meet the expectation which leads towards future intention. Moreover, satisfaction is a powerful tool for spreading optimistic word of mouth (Maxham \& Netemeyer, 2002). A study conducted in online context, also found that service quality, service value and web process control leads towards high satisfaction which generates sales (Ba et al., 2008). The study of Hafeez and Hansu (2010) concluded that mobile-phone users are more fascinated to try new service providers which represent that customer satisfaction is comparatively low as compared with other sectors. Thus, in highly competitive trade zones like cellular industry; customer satisfaction is very essential for long term success. The study of Ahmad et al. (2015) summarized that reliable service, brand trust are major factors that impact customer satisfaction which generate customer loyalty among telecom users. In service industry, customer satisfaction is entirely hooked with catching new customers because when that particular customer uses that service, he/she will match expectations with actual which will generate benefit in future for organization (Khokhar et al., 2011). The main focus for organization is only on to provide differentiate, quick, reliable and distinct services which 
make customer to feel proud and satisfied (Poku et al., 2014). When high quality services are provided to customers they contribute to developing a high repute for brand image which showed positive impact on customer satisfaction (Chao et al., 2015). Moreover, service quality and price flexibility impact customer satisfaction because in developing countries people are more price sensitive as compared with brand trust (Chakraborty \& Sengupta, 2014). The work of Ha (2004) concluded that integrated marketing tools have extensive influence on customer loyalty with medicating role of service quality, store image and customer satisfaction. Thus, based on given literature following hypothesis are proposed

$\mathbf{H}_{3}$ : The relationship of brand image and customer retention is mediating through customer satisfaction.

$\mathbf{H}_{4}$ : The relationship of perceived service quality and customer retention is mediated through customer satisfaction.

Customer Retention: In business world, every cellular operator tries to capture more market share for attaining a sustainable growth pattern based on the policies that focus on customer orientation. The study of Cronin et al. (2000) concluded that customer satisfaction and customer retention level can be enhanced by providing more value added services. Thus, for every organization the most vital and valuable asset is their current customers and these firms adopt different strategies to transform current customers into loyal customers. According to Sahoo et al. (2015) different people have different preferences therefore; organization must understand basic need of buyer to enjoy a long term profitable relationship with existing customers. The work of Mollah (2015) found that satisfaction level differ among different customers and brands because every customer has its own preferences that impact their loyalty. Moreover, prior studies showed that service quality, Image, fair price, complain response and perceive value has strong relationship with customer retention. Gerpott et al. (2001) conducted a research in Germen Mobile cellular telecommunications market and summarized that it is compulsory for an organization to satisfy current customer for long-lasting benefits. Therefore, loyalty Packages with any type of financial reward leads to customer retention (Verhoef, 2003). The work of Schiffman and Kanuk (2004) suggested that customer retention create extensive period of life-value that is more profitable opportunity for firms towards development and sustainability. In these circumstances, buyer satisfaction and faith are important caus es to enhance the consumer retention (Eppie, 2007). A study in Pakistani context revealed that higher the customer satisfaction and switching cost then higher will be the customer retention (Ali et al., 2009). Telecommunication industry faces technological competitive globalization challenges. So, Sun et al. (2014) proposed that customer satisfaction, payment equity, commitment and customer's loyalty had strong impact on customer retention. A research conducted by Caroline and Elizabeth (2014) suggested that service quality and product pricing has a significant relationship with customer satisfaction that leads towards retention. The work of Fullerton (2014) concluded that service quality is a supportive activity to gain customer retention in his model commitment also play a positive mediator role among service quality and buyer retention. Therefore, we proposed following hypothesis:

$\mathbf{H}_{5}$ : Satisfied customers are likely to be retained easily.

Theoretical Framework: Disconfirmation theory argues that "satisfaction is related to the size and direction of the disconfirmation experience that occurs as a result of comparing service performance against expectations". It is a judgment that a product or service feature, or the product or service itself, provided (or is providing) a pleasurable level of consumption-related fulfillment, including levels of under- or overfulfillment. Basically, satisfaction is the result of direct experiences with products or services, and it occurs by comparing perceptions against a standard (e.g. expectations). Prior researchers also indicated that how service was delivered which is more important than the outcome of the service process, and dissatisfaction towards the service often simply occurs when guest's perceptions do not meet their expectations. Moreover, the study of Mattila \& O'Neill (2003) discussed that "amongst the most popular satisfaction theories, its disconfirmation theory which argued that satisfaction is related to the size and direction of the disconfirmation experience that occurs as a result of comparing service performance against expectations". Similarly, Reichhels (1996) suggested that the loyal employees and loyal investors are likely to be able to build an inventory of loyal customer, and that customer's only stay if they had a good value proposition. The framework showed in (Figure-1) comprised of four major variables that expresses the customer's retention antecedents in telecom industry. Perceived service quality and brand image are taken an antecedents which impact customer retentions. Secondly, this study has explored the relationship of perceived service quality and brand image on 
customer retention which is mediated through customer satisfaction because satisfied customers always have a lifetime relationship this is called as customer's retention.

Figure 1: Proposed framework for assessing Customer Retention

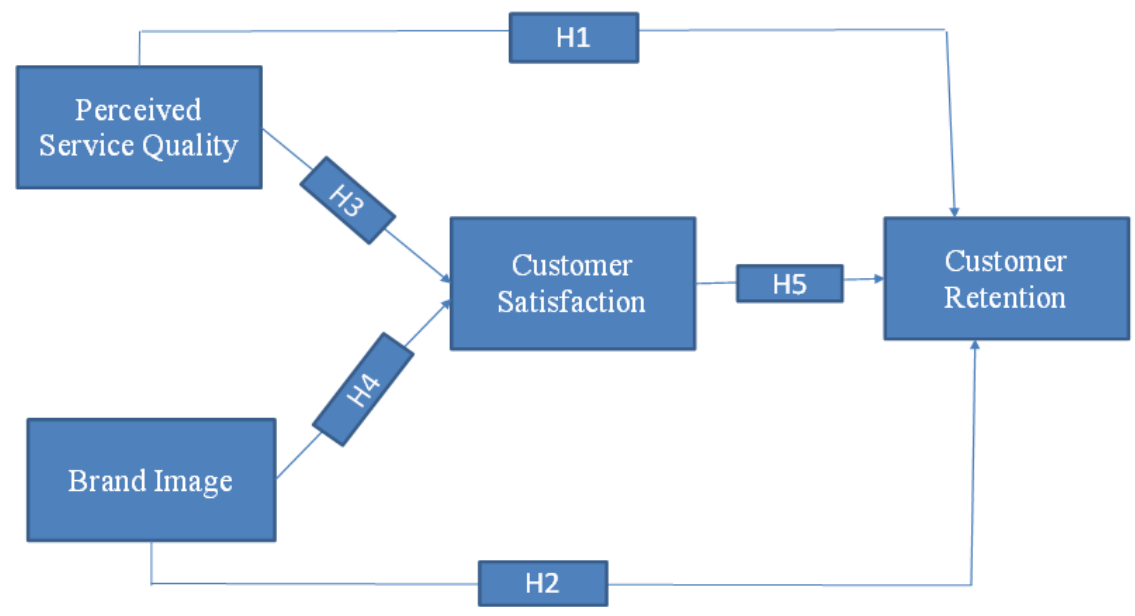

\section{Methodology}

This study was executed with a sample of 310 cellular users in the third largest city of Pakistan, Faisalabad. For this purpose, data were collected through non-probability sampling technique by adopting convenience sampling as a data collection method. As this study followed a quantitative research approach, thus fullystructured questionnaire was utilized as a research instrument. The cellular-network users are selected from both public and private sector to get more precise respond. The data was collected from universities, banks \& different shopping malls. Data were collected from 15th May 2015 to 18th July 2015. Before collecting response from cellular-network users, a pre-tested questionnaire was distributed among colleagues to check the language and context of questionnaire. Finally, 360 questionnaires were distributed to respective respondents for recording their own experience about mobile connection and its services. After refining wrongly filled questionnaires; we get 310 questionnaires with a response rate of $84.33 \%$. This sample size is supported by Comrey \& Lee (1992) which suggested a criterion about sample size: 100=poor, $200=$ fair, $300=$ good, $500=$ very good $\& 1,000$ or more=excellent.

The analysis was conducted through hierarchical linear regression (HLM) and Sobel test technique which test the hypothesized relationship amongst independent, mediating and dependent variables using SPSS. All variables were checked with face validity because they are adopted from prior research. Perceived services quality (PSQ) has eight items which explore dimensions of service-quality designed and approved by Parasuraman et al. (1988). Brand image (BI) was measured by a scale developed by Aaker (1991) which consisted on eight items. Westbrook and Oliver (1987) designed a scale to measure consumer satisfaction (CS) which consisted on ten items. Lastly, items of customer retention (CR) were adopted from the work of Peighambari (2007) which consisted on six questions. Therefore, Perceived service quality (PSQ) consists of eight items and presented a cronbach's alpha of 0.779 , customer satisfaction (CS) consisted on ten items by presenting a cronbach's alpha of 0.812 , customer retention (CR) was measured by six items by presenting a cronbach's alpha of 0.755 and brand image (BI) consisted on six items by presenting a cronbach's alpha of 0.851. The designed questionnaire followed 5-point likert scale from "strongly-disagree to strongly-agree". Questionnaire includes two sections; first part asked about demographics and respondents service usage behavior. Second part record respondents response about Perceived service quality, customer satisfaction, customer retention and brand image.

The demographics of respondents is shown in (Table 1) which described that 85 female respondents participated in the research that was 27.4 percent while 225 males provided with their views that accounted for 72.6 percent of the total sample. Respondents from 18 to 32 years are 180 respondents which accounted for 58.1 percent, while 33 to 47 years of respondents are 127 which represent 40 percent and 48 to 62 years 
of respondents are 3 which represent 1 percent. The question regarding network frequency showed that 82 Mobilink, respondents participated in the research that was 26.5 percent. 81 Ufone, respondents participated in the research that was 26.1 percent. 74 Telenor respondents participated in the research that was 23.9 percent. 34 Warid respondents participated in the research that was 10.9 percent and 40 Zong, respondents participated in the research that was 13 percent of the total sample. From the total 310 respondents; 178 people were working in the organization and doing full time job. That was 57.4 percent of sample.49 respondents are doing half time job. They are 15.8 percent people of sample, 6 people are retired that was 1.9 percent and 9 participants are not working that was 2.9 percent of sample. On the other hand, 68 participants are students that were 21.9 percent of sample. 141 participants secured Master, M.Phil. Or PhD degrees. It means 45.5 percent respondents were holding 18 years or more education. 91 respondents were with Bachelor Degrees in their respective field of discipline with 29.6 percent of the total. 73 respondents completed college degree with 23.5 percent. Remaining 6 percent respondents completed their high school and 1 percent completed their middle school. It is important to highlight that majority of participants are well educated and having education up to graduation or more than it.

Table 1: Demographic profile of respondents $(\mathrm{N}=310)$

\begin{tabular}{lll}
\hline Gender & Frequency & Percent \\
\hline Male & 255 & $72.6 \%$ \\
Female & 85 & $27.4 \%$ \\
Age & & \\
$18-32$ & 180 & $58.1 \%$ \\
$33-47$ & 127 & $40.0 \%$ \\
$48-62$ & 3 & $1.0 \%$ \\
Cellular- Network User & & \\
Mobilink & 82 & $26.5 \%$ \\
Ufone & 81 & $26.2 \%$ \\
Telenor & 72 & $23.3 \%$ \\
Warid & 34 & $10.9 \%$ \\
Zong & 40 & $13 \%$ \\
Education/Qualification & & \\
Middle School & 3 & $1 \%$ \\
High School & 2 & $6 \%$ \\
College & 73 & $23.5 \%$ \\
Bachelor & 91 & $29.4 \%$ \\
Master \& above & 141 & $45.5 \%$ \\
Employment & & \\
Full time job & 178 & $57.4 \%$ \\
Part time job & 49 & $15.8 \%$ \\
Retired & 6 & $1.9 \%$ \\
Un-employed & 9 & $2.9 \%$ \\
Students & 68 & $21.9 \%$ \\
\hline Source: authors own & & \\
\hline
\end{tabular}

Source: authors own calculations

\section{Results}

The (Table 2) showed that the descriptive statistics of the predictors. First column showed the mean of the respective variables. Perceived service quality showed a mean of 4.31. The mean of brand image is 3.81 . Moreover, the mean of customer satisfaction and customer retention is 4.13 and 4.13 , respectively. Second column describe the standard deviation of all variables that is $0.48,0.49,0.46$ and 0.44 for service quality, brand image customer's satisfaction and customer's retention. The correlation matrix gives bi-variate correlation and coefficient between variables pairs for all the observed variables in the research model. The coefficient of correlation shows a linear association between respective variables. Each variable is perfectly 
correlated with itself and so $\mathrm{r}=1$ along the diagonal of the table. Brand image is positively related with the percentage of Services Quality Correlation coefficient of $r=0.62$ and the significant value is less than .001 . Hence we can gain confidence that there is a genuine relationship between those two variables. However, perceived service quality is having a significant relationship with brand image, customer satisfaction towards customer retention. Similarly, positive change in customer satisfaction also represents significant relationship with customer retention.

Table 2: Correlation, mean, standard deviation of variables

\begin{tabular}{lllllll}
\hline & Mean & Std. Dev & PSQ & BI & CS & CR \\
\hline PSQ & 4.31 & 0.48 & 1 & & & \\
BI & 3.81 & 0.49 & $0.624^{* *}$ & 1 & & \\
CS & 4.13 & 0.46 & $0.500^{* *}$ & $0.730^{* *}$ & 1 & \\
CR & 4.13 & 0.45 & $0.553^{* *}$ & $0.699^{* *}$ & $0.741^{* *}$ & 1 \\
\hline
\end{tabular}

PSQ: Perceived Service Quality; BI: Brand Image; CS: Customer Satisfaction \& CR: Customer Retention

**. Correlation is significant at the 0.01 level (2-tailed).

*.Correlation is significant at the 0.05 level (2-tailed).

We use the hierarchical linear regression (HLM) analysis with SPSS. In order to test our hypothesis for that reason, we followed the steps directed by (Muller, Judd \& Yzerbyt, 2005). This study tried to test our $\mathrm{H}_{3}$ and $\mathrm{H}_{4}$ by using multivariate two levels Model 4 under Sobel test with exploratory variable service quality (X), mediator customer satisfaction (M) and customer retention (Y). The Table 3 presented results for $\mathrm{H}_{3}$ which investigate the effect of service quality was shown on customer retention through customer satisfaction. The direct effect (PYX) is significant with the level of ( $<<.01)$. The significant value of path is (PYX $0.240, \mathrm{P}<.01$ ) stated that there is a significant effect of service quality on customer retention that is our regressed variable and it is confirmed $\mathrm{H}_{1}$ "Service quality positively associated with customer retention" is supported. The indirect effect of service quality (PMY*PMX) was also significant with the value of $(0.306, p<.01)$. The independent and mediator variable is significant; this indicates the customer satisfaction is a partially mediator. The total effect of service quality was also significant $(0.546, p<.01)$ and this furnished the support for our $\mathrm{H}_{2}$.Furthermore, the results of (Table 3) also provided significant support for $\mathrm{H}_{3}$ that customer satisfaction partially mediates the relationship of service quality and customer retention.

Table 3: Analyses of Simple Effect (Mediator-CS \& Independent- PSQ)

\begin{tabular}{|c|c|c|c|c|c|c|c|}
\hline $\begin{array}{l}\text { Dependen } \\
\text { t variable }\end{array}$ & Mediator & Inde & $\mathbf{P}_{\mathrm{MX}}$ & $\mathbf{P}_{\mathbf{Y M}}$ & $\begin{array}{l}\text { Direct } \\
\text { effects } \\
\left(P_{Y X}\right)\end{array}$ & $\begin{array}{l}\text { Indirect } \\
\text { effects } \\
\left(P_{Y M} P_{M X}\right)\end{array}$ & $\begin{array}{l}\text { Total effects } \\
\left(P_{Y X}+P_{Y M}\right. \\
\left.P_{M X}\right)\end{array}$ \\
\hline $\begin{array}{l}\text { Customer } \\
\text { retention }\end{array}$ & $\begin{array}{l}\text { Customer } \\
\text { Satisfaction }\end{array}$ & $\begin{array}{l}\text { Service } \\
\text { quality }\end{array}$ & $\begin{array}{l}0.455^{* *} \\
(.045)\end{array}$ & $\begin{array}{l}0.673^{* *} \\
(.046)\end{array}$ & $\begin{array}{l}.240 * * \\
(.041)\end{array}$ & $\begin{array}{l}0.306^{* *} \\
(0.035)\end{array}$ & $0.546^{* *}$ \\
\hline
\end{tabular}

Note: PMX refers to paths from service quality to the mediators (i. e., customer satisfaction), PYM refers to paths from the mediator to the outcome variable (i.e., customer retention). ${ }^{*} \mathrm{p}<.05 ;{ }^{* *} \mathrm{p}<.01$

The result showed in (Table 4) predicted, the correlations between independent variables (service quality) and dependent variable (customer retention), and the mediators (customer satisfaction), showed statistically significant results. A hierarchical regression approach (Baron \& Kenny, 1986) concluded that service quality has a positive relationship with customer retention $(b=.546, p<.01)$. When the domain-specific mediator (customer satisfaction) is entered into the equation, the positive relationships of service quality $(b=.240$, $\mathrm{P}<.01)$, representative partial mediating effects for customer satisfaction $(\mathrm{b}=.674, \mathrm{p}<.01)$ as shown (Table 4$)$. Since the regression coefficients for service quality were decreased after the effects of customer satisfaction were partial mediation effects for customer satisfaction were supported. 
Table 4: Hierarchical Regression Result Testing Mediator (Services Quality * Customer Satisfaction) Customer Retention

\begin{tabular}{lcccc} 
& Beta & $\mathbf{R}$ & $\mathbf{R}^{2}$ & $\mathbf{F}$ \\
\hline $\begin{array}{l}\text { Step 1 } \\
\text { Service Quality }\end{array}$ & $.546^{* *}$ & 0.555 & 0.308 & $136.8^{* *}$ \\
$\begin{array}{l}\text { Step 2 } \\
\text { Services Quality }\end{array}$ & $.240^{* *}$ & 0.771 & 0.595 & $225.591^{* *}$ \\
$\begin{array}{l}\text { Customer satisfaction } \\
\text { Change in R }\end{array}$ & $.674^{* *}$ & & & \\
\hline
\end{tabular}

$\mathrm{N}=310$ un-standardized coefficients are presented. All predictors were centered at their grand means. Independent variable is service quality Mediator is customer satisfaction and customer retention is dependent. ${ }^{*} \mathrm{p}<.05 ;{ }^{* *} \mathrm{p}<.01$

To explore $\mathrm{H}_{4}$, we use the hierarchical linear regression (HLM) analysis with SPSS by using multivariate two levels (Model 4) under Sobel test. The results are presented in (Table 5) which illustrates that the effect of brand image was shown on customer retention through customer satisfaction. The direct effect (PYX) is significant with the level of $(\mathrm{p}<.01)$. The significant value of path is (PYX $0.347, \mathrm{P}<.01)$ which stated that there is a significant effect of brand image on customer retention and it supported $\mathrm{H}_{2}$ that "Brand image positively associated with customer retention". The indirect effect of service quality (PMY*PMX) was also significant with the value of $(0.375, \mathrm{p}<.01)$. The independent and mediator variable are significant while the predicative power of brand image has increased from 0.347 to 0.375 but still it showed significant results. Thus, it indicates that customer satisfaction is a partially mediator which showed support for $\mathrm{H}_{4}$.

Table 5: Analyses of Simple Effect (Mediator-CS \& Independent- BI)

\begin{tabular}{|c|c|c|c|c|c|c|c|}
\hline $\begin{array}{l}\text { Dependent } \\
\text { variable }\end{array}$ & Mediator & t & $\mathbf{P}_{\mathrm{MX}}$ & $\mathbf{P}_{\mathrm{YM}}$ & $\begin{array}{l}\text { Direct } \\
\text { effects } \\
\left(P_{\mathrm{YX}}\right)\end{array}$ & $\begin{array}{l}\text { Indirect } \\
\text { effects } \\
\left(\mathrm{P}_{\mathrm{YM}} \mathrm{P}_{\mathrm{MX}}\right)\end{array}$ & $\begin{array}{l}\text { Total } \\
\text { effects } \\
\left(\mathbf{P}_{\mathrm{YX}}+\mathrm{P}_{\mathrm{YM}}\right. \\
\left.\mathrm{P}_{\mathrm{MX}}\right)\end{array}$ \\
\hline $\begin{array}{l}\text { Customer } \\
\text { retention }\end{array}$ & $\begin{array}{l}\text { Customer } \\
\text { Satisfaction }\end{array}$ & Brand Image & $\begin{array}{l}0.69 * * \\
(.037)\end{array}$ & $\begin{array}{l}0.54^{* *} \\
(.057)\end{array}$ & $\begin{array}{l}.347^{* *} \\
(.054)\end{array}$ & $\begin{array}{l}0.375^{* *} \\
(0.038)\end{array}$ & $0.722^{* *}$ \\
\hline
\end{tabular}

Note: PMX refers to paths from brand image to the mediators (i. e., customer satisfaction), PYM refers to paths from the mediator to the outcome variable (i.e., customer retention). ${ }^{*} \mathrm{p}<.05$; ${ }^{* *} \mathrm{p}<.01$

Table 6: Hierarchical Regression Result Testing Mediator (Brand Image*Satisfaction) Customer Retention

\begin{tabular}{lllll} 
& Beta & $\mathbf{R}$ & $\mathbf{R}^{2}$ & $\mathbf{F}$ \\
\hline $\begin{array}{l}\text { Step 1 } \\
\text { Image }\end{array}$ & $.722^{* *}$ & 0.699 & 0.488 & $293.56^{* *}$ \\
$\begin{array}{l}\text { Step 2 } \\
\text { Image }\end{array}$ & $.347^{* *}$ & 0.777 & 0.603 & $233.60^{* *}$ \\
$\begin{array}{l}\text { Satisfaction } \\
\text { Change in R }\end{array}$ & $.540^{* *}$ & & & \\
\hline
\end{tabular}

$\mathrm{N}=310$ un-standardized coefficients are presented. All predictors were centered at their grand means. Independent variable is Brand Image Mediator is customer satisfaction and customer retention is dependent. ${ }^{*} \mathrm{p}<.05 ;{ }^{* *} \mathrm{p}<.01$

In the following (Table 6), the correlations between independent variables (brand image) and dependent variable (customer retention) and mediators (customer satisfaction) has showed statistically significant results. A hierarchical regression approach (Baron \& Kenny, 1986) was executed which summarized that brand image has a positive relationship with customer retention $(b=.722, p<.01)$. When the domain-specific mediator (customer satisfaction) was entered into the equation, the positive relationships of brand image $(\mathrm{b}=.347, \mathrm{P}<.01)$, representative partial mediating effects of customer satisfaction $(\mathrm{b}=.540, \mathrm{p}<.01)$. It concluded that, regression coefficients for brand image were decreased after the effects of customer 
satisfaction were partial mediation effects for customer satisfaction was supported. Overall results predicted that brand image; service quality and customer satisfaction plays a vital role in the presence of customer retention. This study supports the work of Reichheld (1996) and Storbacka et al. (1994) which suggested that longer utilization of the product by the consumer helps to maintain longer relationship with the organization and ultimately organization retains that customer. Moreover, Bergstrom \& Bresnahan (1996) discovered that better the brand image sets in the mind of customers the number of retained customer will automatically be increased. The results of $\mathrm{H} 1$ and $\mathrm{H} 2$ also endorse the outcome of Peng \& Qing (2006) and Boohene \& Agyapong (2011) which showed that brand image has a positive significant impact on customer retention. These all factors are like chain that is knotted with one another. The results showed evidence that high service quality and distinctive brand image will make the customers satisfied that leads towards customer retention and developing future relationship.

Discussion: The retained customers act as assets for service organizations because they promote positive word of mouth and guide them to create new attractive packages for new customers. Also, the work of Storbacka et al. (1994) discovered that the longer utilization of the product/service by the customer help to maintain longer relationship with the organization and ultimately get a retained customer. In telecommunication sector, majority of customer showed their experience with one service provider not more than one year which depicted that better services are needed. The service quality is the step through which a strong brand image is created in the mind of customer, which helps the customer to become eventually a loyal customer for that organization (Brown \& Gulycz, 2001). When organization provides best services quality that ultimately attracts the customer which represent that there is a positive relationship between perceived service quality and customer retention. Moreover, existing customers not only ensure higher sales but also support organization in providing additional attractive product/services to new customers. Customer retention is also a vital tool for organizations to spread product knowledge that decrease marketing cost. Similarly, Fornell (1992) approved that satisfaction have a main reason of retention. The service quality increases customer satisfaction which is based on actual performance and expectation that customer perceived in its mind. Furthermore, organizations make policies to retain customers by delivering them various innovative and attractive business deals which promote customer loyalty. If customers are satisfied with the product/service then retention appears in customer's future decision-making that provide feedback about product/service experience and recommendation about upgrading (Othman et al., 2015). The findings suggested that cellular service providers must consider the importance of customer retention. Every customer is an essential asset for any organization, either public organization or private organization. Thus, Customers could be captured on the basis of services quality, better customer care that includes resolving customer complain at time, giving them special care, giving them some gifts on special events.

To provoke the competing environment in telecommunication industry, companies have to learn and build their understanding about admirable features for service quality and customer satisfaction. Customer retention is very crucial aspect in telecom sector of Pakistan. A long-term relationship is required to encourage customers for retaining them as loyal users (Stathopoulou \& Balabanis, 2016). Moreover, this study identified that brand image influence consumer purchase decision through satisfaction. This research supported the finding of Etzel et al. (2001) which explored brand loyalty in service sector depends on customer retention and service quality. To determine core factors that influence mobile phone user's retention behavior are changing due to the advancement of technologies. When an organization provides proper quality services, the image of the organization is robust and obvious in the minds of customers along with other appropriate dimensions this leads towards customer satisfaction.

\section{Conclusion}

In an extensive world of competition and success, every single organization is looking forward to achieve ever-lasting relationship with customers. Organizations nowadays are continuously trying to satisfy their customers in order to retain them for time-consuming era. Customer satisfaction with the finest service quality is needed to be provided by cellular firms to maintain customer loyalty. On the other hand, brand image act as a strong predictor to retain customer in telecom sector of Pakistan because people perceive their product/service packages as best with low price-rate. So, the organization that provides services like low calling rates, SMS (short message services), internet packages like 3G and 4G could easily retain existing 
customers etc. People like to avail their services that are within their budget range. Nowadays, Innovative technologies attract new customers which cause switching behavior and to retain such customer, organizations have to provide them value-added services with best service quality. Service quality has got scholarly attention during past years due to digital connectivity. The relationship between perceived service quality and customer retention provide evidence about the existence of brand awareness and consumer knowledge (Poku et al., 2014). The study found that brand image is the most important attribute for customer retention. In service sector like telecom, higher standard of service quality will lead consumer to be fully satisfied and acknowledged their brand image which improve consumer expectation. The theoretical perspective concentrates on customer retention behavior in telecommunication sector. This study provided a framework that will help marketing managers to assess customer re-purchase and retention decision based on service quality and brand image. Therefore, when telecom firms deliver high-standard service quality it boosts customer satisfaction because retaining existing customer is very cost-effective as compared with generate a new customer. Existing customers also increase sales volume by responding to additional services that were initialized by an organization. According to Lai (2004) perceived service quality enhanced customer satisfaction no matter what their gender or race. When companies target to enhance their loyalty program, they first attract their retained consumers that allow telecom firms to improve their service quality and brand image.

From managerial perspective, young adults are extremely involved in using other services of telecom firms such as (SMS, MMS and internet browsing). Therefore, marketing manager should launch those promotional activities that include such attributes for customer retention. Thus, it is mandatory for managers to provide higher service quality every-day to their customer by solving consumer complaints, giving them opportunities to participate in various brand promotional activities. Customer who is satisfied resulted in guiding organization to create a pool of preferred customers that formulate brand advocacy. Thus, consistency in brand attributes is vital for organization to retain customer. The vital features for attracting new customer are to give them service quality with low price. Results of this study proved that service quality and brand image strength customer retention. Thus, retained customer spread positive WOM which drive to gain financial benefits to telecom firms. All of these research factors are like a knitted chain, where every element played an important role in product popularity and sales. Future research could explore more indepth factors for customer retention strategies based on brand awareness and its popularity among target customers.

\section{Reference}

Aaker, D. A. (1991). Managing Brand Equity. The Free Press. New York. NY.

Ahmad, J., Hussain, M. \& Rajput, A. (2015). Customer loyalty framework of telecommunication service market. International Journal of Managing Value and Supply Chains, 6(1), 83.

Ahmad, Z., Ahmed, I., Nawaz, M. M., Usman, A., Shaukat, M. Z. \& Ahmad, N. (2010). Impact of Service Quality of Short Messaging Service on Customers Retention; an Empirical Study of Cellular Companies of Pakistan. International Journal of Business and Management, 5(6), 154-160.

Ahmed, M. M., Nawaz, A., Usrnan, M., Shaukat, Z., Ahmed, N. \& Rehman, W. (2010). A Mediation of Customer Satisfaction Relationship between Service Quality and Repurchase Intentions for the Telecom Sector in Pakistan: A Case Study of University Students. African Journal of Business Management, 4(16), 34573462.

Ali, J. F., Ali, I., Rehman, K., Yilmaz, A. K., Safwan, N. \& Afzal, H. (2010). Determinants of Consumer Retention in Cellular Industry of Pakistan. African Journal of Business Management, 4(12), 2402-2408.

Ali, J. F., Ali, I., Waseemullah, A. I. \& Akram, M. (2009). Determinants of Customer Retention In Cellular Industry In Pakistan. Proceeding 2nd CBRC.

Ba, S. \& Johansson, W. C. (2008). An exploratory study of the impact of e-service process on online customer satisfaction. Production and Operations Management, 17(1), 107-119.

Bahia, K. \& Nantel, J. (2000). A reliable and valid measurement scale for the perceived service quality of banks. International journal of bank marketing, 18(2), 84-91.

Baron, R. M. \& Kenny, D. A. (1986). The moderator-mediator variable distinction in social psychological research: Conceptual, strategic, and statistical considerations. Journal of personality and social psychology, 51(6), 1173. 
Bergstrom, A. J. \& Bresnahan, J. M. (1996). How Banks Can Harness the Power of Branding. US Banker, 106(3), 81-82.

Boohene, R. \& Agyapong, G. K. (2011). Analysis of the antecedents of customer loyalty of telecommunication industry in Ghana: The case of Vodafone (Ghana). International Business Research, 4(1), 229.

Brown, S. A. \& Gulycz, M. (2001). Customer relationship management: Astrategic imperative in the world of ebusiness: New York: Wiley.

Brown, S. P. \& Chin, W. W. (2004). Satisfying and retaining customers through independent service representatives. Decision Sciences, 35(3), 527-550.

Caroline, M. \& Elizabeth, M. (2014). Determinants of Customer Retention in Commercial Banks in Tanzania. Journal of Finance and Bank Management, 2(1), 09-30.

Caruana, A. (2002). Service loyalty: The effects of service quality and the mediating role of customer satisfaction. European journal of marketing, 36(7/8), 811-828.

Casadesus, M. (2014) .Assessing the effects of online service quality on loyalty and the mediation role of customer satisfaction and perceived value. Center for Quality 17(3), 276-340.

Cavana, R. Y., Corbett, L. M. \& Lo, Y. L. (2007). Developing zones of tolerance for managing passenger rail service quality. International Journal of Quality \& Reliability Management, 24(1), 7-31.

Chakraborty, S. \& Sengupta, K. (2014). Structural equation modeling of determinants of customer satisfaction of mobile network providers: Case of Kolkata, India. IIMB Management Review, 26(4), 234-248.

Chao, R. F. (2015). The Influence of Service Quality, Brand Image, and Customer Satisfaction on Customer Loyalty for Private Karaoke Roomsin Taiwan. source: The Journal of Global Business Management, 11, 59-67.

Chiang, C. F. \& Jang, S. S. C. (2007). The effects of perceived price and brand image on value and purchase intention: Leisure travelers' attitudes toward online hotel booking. Journal of Hospitality Marketing and Management, 15(3), 49-69.

Christopher, M. (1996). From brand values to customer value. Journal of Marketing Practice: applied marketing science, 2(1), 55-66.

Comrey, A. L. \& Lee, H. B. (1992). Interpretation and application of factor analytic results. Comrey AL, Lee HB. A first course in factor analysis, 2.

Cronin-Jr, J. J. \& Taylor, S. A. (1992). Measuring service quality: a reexamination and extension. The journal of marketing, 2, 55-68.

Cronin-Jr., J. J., Brady, M. K. \& Hult, G. T. M. (2000). Assessing the effects of quality, value, and customer satisfaction on consumer behavioral intentions in service environments. Journal of Retailing, 76(2), 193-218.

Davies, G., Chun, R., daSilva, R. \& Roper, S. (2003). Corporate Reputation and Competitiveness. London: Routledge, 2(1), 55-66.

Ene, S. \& Özkaya, B. (2014). A study on corporate image, customer satisfaction and brand loyalty in the context of retail stores. Asian Social Science, 10(14), 52.

Eppie, Y. S. (2007). Factors Affecting Customer Retention In Internet Banking among Hong Kong Professionals and Business Practitioners. University of Newcastle, 17(3), 317-340.

Etzel, M. J., Walker, B. J. \& Stanton, W. J. (2001). Marketing management (12th ed.). McGraw-Hill.

Fornell, C. (1992). A National Customer Satisfaction Barometer: The Swedish Experience. Journal of Marketing, $56(1), 6-21$.

Fullerton, G. (2014). The moderating effect of normative commitment on the service quality-customer retention relationship. European Journal of Marketing, 48(3/4), 657-673.

Gerpott, T. J., Rams, W. \& Schindler, A. (2001). Customer Retention, Loyalty, and Satisfaction in the German Mobile Cellular Telecommunications Market. Telecom Policy, 25(4), 249-269.

Ha, H. Y. (2004). Factors influencing consumer perceptions of brand trust online. Journal of Product \& Brand Management, 13(5), 329-342.

Hafeez, S. \& Hasnu, S. A. F. (2010). Customer satisfaction for cellular phones in Pakistan: A case study of Mobilink. Business and economics research journal, 1(3), 35.

Hanzaee, K. H. \& Farsani, T. (2011). The Effects of Brand Image and Perceived Public Relation on Customer Loyalty. World Appl. Sci. J., 13 (2), 277-286.

Henkel, D., Houchaime, N., Locatelli, N., Singh, S., Zeithaml, V. A. \& Bittner, M. J. (2006). The impact of emerging WLANs on incumbent cellular service providers in the USMJ Services marketing. 
Holland, J. \& Menzel Baker, S. (2001). Customer participation in creating site brand loyalty. Journal of Interactive Marketing, 15(4), 34-45.

Khokhar, S. Z., Hussain, F., Qureshi, T. M., Anjurn, I., Samran, A. \& Arshad, R. (2011). Only Customer Satisfaction and Customer Loyalty is Not Enough: A Study of Pakistan's Telecom Sector. African Journal of Business Management, 5(24), I 0 J 76-10181.

Kim, M. K., Park, M. C. \& Jeong, D. H. (2004). The effects of customer satisfaction and switching barrier on customer loyalty in Korean mobile telecommunication services. Telecommunications policy, 28(2), 145-159.

Kouser, R., Qureshi, S., Shahzad, F. A. \& Hasan, H. (2012). Factors influencing the customer's satisfaction and switching behavior in cellular services of Pakistan. Interdisciplinary Journal of Research in Business, 2(1), 15-25.

Lai, T. L. (2004). Service Quality and Perceived Value's Impact on Satisfaction Intention and Usage of Short Message Service (SMS). International systems Frontiers, 6(4), 353-368.

Lee, G. G. \& Lin, H. F. (2005). Customer perceptions of e-service quality in online shopping. International Journal of Retail \& Distribution Management, 33(2), 161-176.

Lee, H., Lee, Y. \& Yoo, D. (2000). The determinants of perceived service quality and its relationship with satisfaction. Journal of services marketing, 14(3), 217-231.

Lin, J. S. C. \& Wu, C. Y. (2011). The role of expected future use in relationship-based service retention. Managing Service Quality: An International Journal, 21(5), 535-551.

Mansouri, S. H. \& Pakia, M. M. (2015). Investigation of the Effect of Brand Image and Service Quality on trust, commitment and Behavioral Intentions. Asian Journal of Research in Marketing, 4(1), 87-99.

Mansouri, S. H. \& Pakia, M. M. (2015). Investigation of the Effect of Brand Image and Service Quality on trust, commitment and Behavioral Intentions. Asian Journal of Research in Marketing, 4(1), 87-99.

Mattila, A. S. \& O'Neill, J. W. (2003). Relationships between hotel room pricing, occupancy, and guest satisfaction: A longitudinal case of a midscale hotel in the United States. Journal of Hospitality \& Tourism Research, 27(3), 328-341.

Maxham, J. G. \& Neterneyer, R. G. (2002). Modeling Customer Perceptions of Complaint Handling Overtime: The Effects of Perceived Justice on Satisfaction and Intent. Journal of' Retailing, 78(4), 239-252.

Mollah, S. A. (2015). Factors Affecting Customer Satisfaction and Its Level among the Mobile Customers in United Kingdom (UK). European Journal of Business and Management, 7(7), 122-149.

Muller, D., Judd, C. M. \& Yzerbyt, V. Y. (2005). When moderation is mediated and mediation is moderated. Journal of personality and social psychology, 89(6), 852.

Ngie, K. L. M. \& George, A. (2014). Conference Proceeding: A New Service-Quality Model to enhance Customer Retention In the Hong Kong Fast-Food Restaurant Industry, 56(1), 6-21.

Ogba, I. E. \& Tan, Z. (2009). Exploring the impact of brand image on customer loyalty and commitment in China. Journal of Technology Management in China, 4(2), 132-144.

Oh, H. (1999). Service quality, customer satisfaction, and customer value: A holistic perspective. International Journal of Hospitality Management, 18(1), 67-82.

Orel, F. D. \& Kara, A. (2014). Supermarket self-checkout service quality, customer satisfaction, and loyalty: Empirical evidence from an emerging market. Journal of Retailing and Consumer Services, 21(2), 118129.

Othman, H. A. \& Amandu, Y. I. A. (2015). Components of Customer Retention Strategy in Mobile Telephone Industry in Malaysia: Structural Equation Modeling (Sem). Global Journal of Management And Business Research, 15(3).

Parasuraman, A., Zeithaml, V. \& Berry, L. (1988). SERVQUAL: A Multiple-Item Scale for Measuring Consumer Perceptions of Service Quality. Journal of Retailing, 64(1), 12-40.

Parasuraman, A., Zeithaml, V. A. \& Berry, L. L. (1994). Alternative scales for measuring service quality: a comparative assessment based on psychometric and diagnostic criteria. Journal of Retailing, 70(3), 201-230.

Peighambari, K. (2007). Developing and testing a model for explaining customer retention formation: Case of Iranian mobile telecommunication services.

Peng, L, W. Y. \& Qing, K. (2006). Impact of Relationship Marketing Tactics (RMTs) on Switchers and Stayers in a Competitive Service Industry. Journal of Marketing Management, 2, 25-59. 
Poku, K., Ansah, M. O. \& Lamptey, D. I. (2014). The Impact of Service Quality Delivery on Customer Loyalty in the Telecommunication Industry: A Case Study of Expresso Telecom, Ghana. Journal of Research in Marketing, 3(1), 212-221.

Poku, K., Ansah, M. O. \& Lamptey, D. I. (2014). The Impact of Service Quality Delivery on Customer Loyalty in the Telecommunication Industry: A Case Study of Expresso Telecom, Ghana. Journal of Research in Marketing, 3(1), 212-221.

PTA. (2014). Cell Phone Industry in Pakistan. Retrieved on $1^{\text {st }}$ March 2015 <http://www.pta.gov.pk/index.php?option=com_content\&task=view\&id=583\&catid=150\&Itemid=7 47>

Reichheld, F. F. (1996). The quest for loyalty: creating value through partnership. Harvard Business Press.

Reimann, M., Lünemann, U. F. \& Chase, R. B. (2008). Uncertainty avoidance as a moderator of the relationship between perceived service quality and customer satisfaction. Journal of Service Research, 11(1), 6373.

Rust, R. \& Zahorik, A. J. (1993). Customer Satisfaction, Customer Retention, and Market Share. Journal of Retailing, 69(2), 193-215

Sahoo, A. K., Kar, B. B. \& Das, S. (2015). Differentiated Service is the Success Measure: An investigation in Telecom Industry Odisha, India. Mediterranean Journal of Social Sciences, 6(4).

Santos, J. (2003). E-service quality: a model of virtual service quality dimensions. Managing Service Quality: An International Journal, 13(3), 233-246.

Schiffman, L. G. \& Kanuk, L. L. (2004). Consumer Behavior (10 ed.). Harlow, England: Prentice Hall Inc.

Sondoh, S. L., Omar, M. W., Wahid, N. A., Ismail, I. \& Haru, A. (2007). The Effect of Brand Image on Overall Satisfaction and Loyalty Intention in the Context of Color Cosmetic. Journal Asian Academy of Management, 12(1), 83-107.

Stathopoulou, A. \& Balabanis, G. (2016). The effects of loyalty programs on customer satisfaction, trust, and loyalty toward high-and low-end fashion retailers.

Storbacka, K., Strandvik, T. \& Gronroos, C. (1994). Managing customer relationships for profit: the dynamics of relationship quality. International journal of service industry management, 5(5), 21-38.

Sum Chau, V. \& Kao, Y. Y. (2009). Bridge over troubled water or long and winding road? Gap-5 in airline service quality performance measures. Managing Service Quality: An International Journal, 19(1), 106-134.

Sun, B., Wilcox, R. \& Zhu, T. (2014). Ignoring your best customer? An investigation of customer satisfaction, customer retention and their financial impact. Journal of Relationship Marketing, 1(6), 87-116.

Tsai, S. P. (2014). Love and satisfaction drive persistent stickiness: investigating international tourist hotel brands. International Journal of Tourism Research, 16(6), 565-577.

Tsoukatos, E. \& Rand, G. K. (2006). Path analysis of perceived service quality, satisfaction and loyalty in Greek insurance. Managing Service Quality: An International Journal, 16(5), 501-519.

Verhoef, P. C. (2003). Understanding the Effect of Customer Relationship Management Efforts on Customer Retention and Customer Share Development. Journal of Marketing, 67, 3045.

Westbrook, R. A. \& Oliver, R. L (1987). Developing Better Measures of Consumer Satisfaction: Some Preliminary Results. In Advances in Consumer Research. Association for Consumer Research, 8(1), 9499.

Yang, Z., Jun, M. \& Peterson, R. T. (2004). Measuring customer perceived online service quality: scale development and managerial implications. International Journal of Operations \& Production Management, 24(11), 1149-1174.

Yeh, C. H. (2014). The Impact of Store Image, Perceived Value, Sales Promotion, and Customer Satisfaction on Repurchase Intention-A Case of C Warehouse Store Customers.

Yoshida, M. \& James, J. D. (2010). Customer satisfaction with game and service experiences: Antecedents and consequences. Journal of sport management, 24(3), 338-361.

Zeitharnl, V. A. (2000). Service Quality, Profitability and the Economic Worth of Customers: What We Know and What We Need to Learn. Journal of the Academy of Marketing Science, 28(1), 67-85. 